Marquette University

e-Publications@Marquette

Chemistry Faculty Research and Publications

Chemistry, Department of

$1-1-2016$

X-ray Structure and Properties of the Ferrous Octaethylporphyrin Nitroxyl Complex

Nagabhushanam Kundakarla

Marquette University

Sergey V. Lindeman

Marquette University, sergey.lindeman@marquette.edu

Hafiz Md. Rahman

Marquette University

Michael D. Ryan

Marquette University, michael.ryan@marquette.edu

Accepted version. Inorganic Chemistry, Vol. 55, No. 5 (2016): 2070-2075. DOI. (C) 2016 American Chemical Society. Used with permission. 
NOT THE PUBLISHED VERSION; this is the author's final, peer-reviewed manuscript. The published version may be accessed by following the link in the citation at the bottom of the page.

\title{
X-ray Structure and Properties of the Ferrous Octaethylporphyrin Nitroxyl Complex
}

\author{
Nagabhushanam Kundakarla \\ Department of Chemistry, Marquette University \\ Milwaukee, WI \\ Sergey Lindeman \\ Department of Chemistry, Marquette University \\ Milwaukee, WI \\ Md. Hafiz Rahman \\ Department of Chemistry, Marquette University \\ Milwaukee, WI \\ Michael D. Ryan \\ Department of Chemistry, Marquette University \\ Milwaukee, WI
}

Synopsis: The X-ray crystal structure of $[\mathrm{Fe}(\mathrm{OEP})(\mathrm{NO})]^{-}$is reported, along with infrared and NMR spectra. The $\mathrm{Fe}-\mathrm{N}-\mathrm{O}$ bond angle decreased upon reduction and was consistent with those in other $\{\text { FeNO }\}^{8}$ complexes. The ${ }^{1} \mathrm{H}$ NMR spectrum was reported, which was different from those for other $S=0$ metalloporphyrin complexes due to the displacement of the Fe atom from the porphyrin plane. This spectrum was consistent with DFT calculations. 


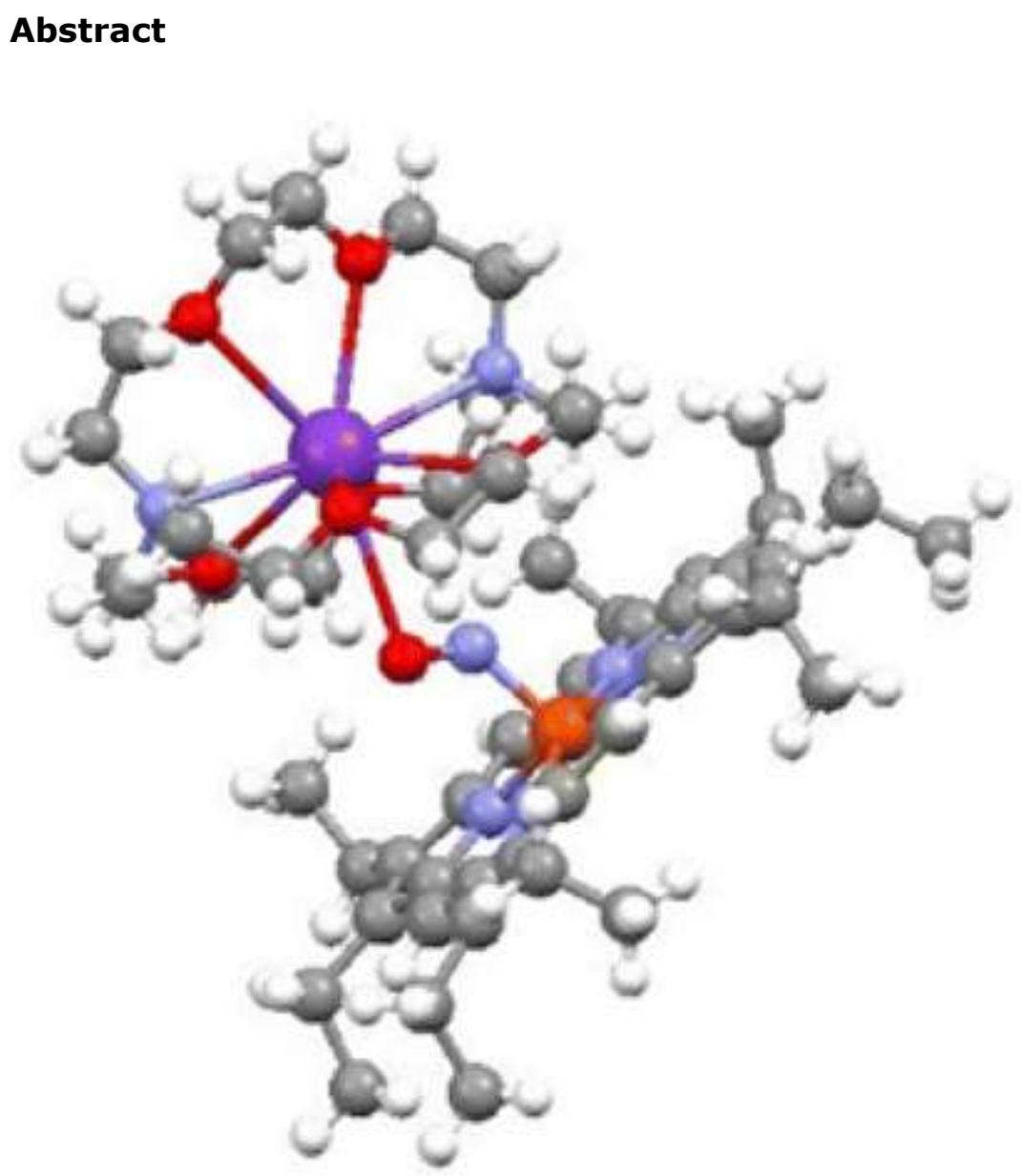

The preparation and characterization of the iron octaethylporphyrin nitroxyl ion, $\left[\mathrm{Fe}(\mathrm{OEP})(\mathrm{NO})^{-}\right]$, is reported. The complex was synthesized by the oneelectron reduction of $\mathrm{Fe}(\mathrm{OEP})(\mathrm{NO})$ using anthracenide as the reducing agent. The compound was isolated as the potassium (2.2.2)cryptand salt. The anion was characterized using $X$-ray analysis with visible and infrared spectroscopy. The spectral features of the iron nitroxyl complex were consistent with previous literature reports. The important structural changes upon reduction were a significant decrease in the $\mathrm{Fe}-\mathrm{N}-\mathrm{O}$ bond angle from $142^{\circ}$ to $127^{\circ}$ and an increase in the $\mathrm{N}-\mathrm{O}$ bond length from that in the starting nitrosyl moiety. The porphyrin ring became significantly less planar upon reduction, but the displacement of the iron atom from the 24-atom plane was essentially unchanged. In spite of the attempt to encapsulate the potassium ion with the (2.2.2)cryptand, significant interaction between $\mathrm{K}^{+}$and the oxygen of the nitroxyl were observed, indicating a contact ion pair in the crystal structure. Comparison between the experimental structure and the DFT-calculated parameters were reported. The results are consistent with the $\mathrm{Fe}-\mathrm{N}-\mathrm{O}$ moiety being the site of the reduction, with little evidence for the reduction of the iron itself or the porphyrin ring. The proton NMR spectrum was also obtained, 
and the chemical shifts were significantly different from other $S=0$ metalloporphyrin complexes. These shifts, though, were consistent with the DFT calculations.

\section{Introduction}

Iron porphyrin nitroxyl compounds have attracted considerable interest due to their varied chemical and biochemical reactions. The nitroxyl, along with its conjugate acid (HNO), is involved in a number of biochemical processes, including microbial denitrifying enzymes, ${ }^{1}$ as well as providing therapeutic benefits. ${ }^{2,3}$ Ferrous nitroxyl species have been proposed as intermediates in nitric oxide reductase (NorBC) ${ }^{4}$ and cytochrome P450nor. ${ }^{5,6}$ The electronic structure and biological reactivity of $\mathrm{Fe}(\mathrm{HNO})$ complexes have been recently reviewed. ${ }^{7}$ Particular interest has been focused on $[\mathrm{Fe}(\mathrm{P})(\mathrm{NO})]^{-}$because of its relationship to $\mathrm{Fe}(\mathrm{P})(\mathrm{HNO})$ (where $\mathrm{P}=$ porphyrin). The cyclic voltammetry of $\mathrm{Fe}(\mathrm{OEP})(\mathrm{NO})$ and $\mathrm{Fe}(\mathrm{TPP})(\mathrm{NO})$ (OEP = octaethylporphyrin; TPP = tetraphenylporphyrin) was reported by Olson et al. ${ }^{8,9}$ In the latter work, the visible spectroelectrochemistry of the oxidation and reduction of these complexes was reported. ${ }^{9}$ Choi and Ryan ${ }^{10}$ examined the voltammetry of $\mathrm{Fe}(\mathrm{TPP})(\mathrm{NO})$ in the presence of amines. Mu and Kadish ${ }^{11}$ used FTIR spectroelectrochemistry to characterize the $\mathrm{v}_{\mathrm{NO}}$ band in $[\mathrm{Fe}(\mathrm{P})(\mathrm{NO})]^{+}$. Choi et al. ${ }^{12}$ used resonance Raman spectroscopy to obtain the spectrum of $[\mathrm{Fe}(\mathrm{TPP})(\mathrm{NO})]^{-}$in $\mathrm{THF}$, and identify its $\mathrm{V}_{\mathrm{NO}}$ and $\mathrm{V}_{\mathrm{Fe}-\mathrm{No}}$ bands. The FTIR spectroelectrochemistry of $\mathrm{Fe}(\mathrm{OEP})(\mathrm{NO})$ was reported by Wei and Ryan, ${ }^{13}$ and measured the $V_{\mathrm{NO}}$ band of $[\mathrm{Fe}(\mathrm{OEP})(\mathrm{NO})]^{-}$to be $1441 \mathrm{~cm}^{-1}$, a decrease of $229 \mathrm{~cm}^{-1}$ upon reduction. Goodrich et al. ${ }^{14}$ used visible and FTIR spectroelectrochemistry to study the reduction of a bis picket fence porphyrin nitrosyl and observed a similar decrease in the $\mathrm{v}_{\mathrm{NO}}$ band in the infrared.

Scheidt and Frisse ${ }^{15}$ reported on the X-ray structure of $\mathrm{Fe}(\mathrm{TPP})(\mathrm{NO})$. Two crystal structures of $\mathrm{Fe}(\mathrm{OEP})(\mathrm{NO})$ were later reported by Scheidt et al. ${ }^{16}$ Prior to this work, iron porphyrin nitrosyl structures suffered from disorder. ${ }^{15,17,18}$ Later Goodrich et al. ${ }^{14}$ also obtained a single NO orientation with a bis picket fence iron porphyrin. All of the structures showed a bent Fe-N-O moiety, with an angle of about $144^{\circ}$ and a tilt of about $6-8^{\circ}$. The structures of two ferric porphyrin nitrosyl complexes, $[\mathrm{Fe}(\mathrm{TPP})(\mathrm{NO})]\left[\mathrm{ClO}_{4}\right]$ and 
$\left[\mathrm{Fe}(\mathrm{TPP})(\mathrm{NO})\left(\mathrm{H}_{2} \mathrm{O}\right)\right]\left[\mathrm{ClO}_{4}\right]$, were reported by Scheidt et al. ${ }^{19}$ The Fe$\mathrm{N}-\mathrm{O}$ bond angles were about $175-177^{\circ}$, close to linear. The isolation of the first $\left\{\mathrm{FeNO}^{8}\right.$ porphyrin complex, $\left[\mathrm{Fe}\left(\mathrm{TFPPBr}_{8}\right)(\mathrm{NO})\right]^{-}\left(\mathrm{TFPPBr}_{8}\right.$ = tetrakis (pentafluorophenyl)octabromoporphyrin), was reported by Pellegrino et al. ${ }^{20}$ The $\mathrm{v}_{\mathrm{NO}}$ value for the complex decreased from 1715 to $1547 \mathrm{~cm}^{-1}$, consistent with previous solution studies of $\mathrm{Fe}(\mathrm{P})(\mathrm{NO})^{-} .^{12-14}$ Recently, the structure of $\left[\mathrm{Fe}\left(\mathrm{TFPPBr}_{8}\right)(\mathrm{NO})\right]^{-}$was reported. ${ }^{21}$ An Fe-N-O bond angle of $122^{\circ}$ was reported for this complex. The isolation of $[\mathrm{Fe}(\mathrm{OEP})(\mathrm{NO})]^{-}$has not yet been reported. The octaalkylporphyrins are structurally much closer to the physiological porphyrins than is $\mathrm{TFPPBr}_{8}$, and the isolation and characterization of this complex would be of great value. In this paper, we report on the X-ray crystal structure of $[\mathrm{Fe}(\mathrm{OEP})(\mathrm{NO})]^{-}$.

\section{Experimental Section}

Iron octaethylporphyrin chloride, zinc octaethylporphyrin, THF, 2.2.2-cryptand $(4,7,13,16,21,24$-hexaoxa-1,10diazabicyclo[8.8.8] hexacosane), anthracene, and THF were obtained from Sigma-Aldrich Chemical Co. The nitrosyl complex $\mathrm{Fe}(\mathrm{OEP})(\mathrm{NO})$ (1) and its ${ }^{15} \mathrm{~N}$ analogue were synthesized by literature methods. ${ }^{22}$ Meso-deuteration of $\mathrm{H}_{2} \mathrm{OEP}$ was accomplished using the $\mathrm{D}_{2} \mathrm{SO}_{4} / \mathrm{D}_{2} \mathrm{O}$ method. ${ }^{23} 1$-Methylimidazole- $d_{3}$ was obtained from CDN Isotopes. Anhydrous tetrahydrofuran (THF) was refluxed in the presence of sodium and benzophenone under nitrogen until the solution was blue. The reducing agent, a $0.20 \mathrm{M}$ solution of the potassium cryptand salt of anthracenide, was generated in the glovebox by dissolving equimolar amounts of anthracene and 2.2.2-cryptand in THF. A small amount of potassium metal was then added to this solution. After reaction, the excess potassium metal was removed and disposed of properly. Caution: potassium metal is very reactive and can cause fire or explosion due to the formation of $\mathrm{H}_{2}$ and the exothermicity of its reaction with water or acidic protons. The complex $\mathrm{Fe}(\mathrm{OEP})(\mathrm{NO})$ was dissolved in THF, and 1 equiv of potassium cryptand anthracenide was added. The solvent was removed, and the solid was then redissolved in THF. Crystallization was obtained by layering with heptane. The infrared spectra were obtained with a Thermo Nicolet-FTIR spectrophotometer (Model 670 Nexus) with an MCT detector. Infrared spectra of solid materials were collected as $\mathrm{KBr}$ pellets. Analysis of the 
crystal packing distances and planarity of the porphyrin ring was carried out using the program MERCURY from the Cambridge Crystallographic Data Center (University of Cambridge, Cambridge, U.K.). ${ }^{1} \mathrm{H}$ NMR spectra were collected at room temperature with a Varian $400 \mathrm{MHz}$ spectrometer.

Electronic structure, NMR, and vibrational spectral calculations were carried out using the m06, m06L, mpwvwn, and bp86 DFT functionals and the TZVP basis set for all elements except for the iron atom using the Gaussian 09 suite of programs. ${ }^{24-26}$ Only the m06 functional was used for the NMR calculations. The Wachters basis set was used for iron. ${ }^{27}$ All calculations converged using the tight optimization criteria.

\section{Results and Discussion}

\section{X-ray Crystal Structure}

The reduction of $\mathrm{Fe}(\mathrm{OEP})(\mathrm{NO})$ (1) was carried out using potassium (2.2.2)cryptand anthracenide as the reducing agent as described in the Experimental Section. The visible spectrum of the chemically generated $[\mathrm{Fe}(\mathrm{OEP})(\mathrm{NO})]^{-}$was consistent with the literature values. ${ }^{9,12,28}$ The ferrous nitroxyl complex [Fe(OEP)(NO) ] (2) was crystallized as the potassium cryptand salt. The salt crystallized with two cations, two anions, and one anthracene molecule in an asymmetric unit. In general, the bond lengths and angles of both porphyrin structures in the asymmetric unit were within experimental error. There are two important exceptions: the K1-O1 (K1A-O1A; 3.125 and $3.278 \AA$, respectively) and 01-N5 (O1A-N5A) (Table 2) distances differed by more than the experimental error. While the $\mathrm{K} 1-$ O1/K1A-O1A distances differed, the K1-O1-N5/K1A-O1A-N5A bond angles were similar ( $98.57^{\circ}$ versus $98.36^{\circ}$, respectively), but the uncertainties were large $\left(0.18^{\circ}\right)$. These differences in the ionic bond lengths ( $\mathrm{K}-\mathrm{O}$ distance) and the uncertainties in the $\mathrm{K}-\mathrm{O}-\mathrm{N}$ bond angles are probably due to the thermal motion of the NO group. The stronger the thermal motion, the shorter the bond will appear. ${ }^{32}$ In our case, the thermal vibrations of the $\mathrm{O}$ and $\mathrm{N}$ atoms forming the shorter $\mathrm{N}=\mathrm{O}$ bond are $20-25 \%$ stronger than the longer bond. The structure of the cation and anion is shown in Figure 1, and the crystallographic 
data and structure refinement details are shown in Table 1. Additional structural data are given in the Supporting Information. The important bond lengths and angles are shown in Table 2, along with a comparison with those of related complexes.

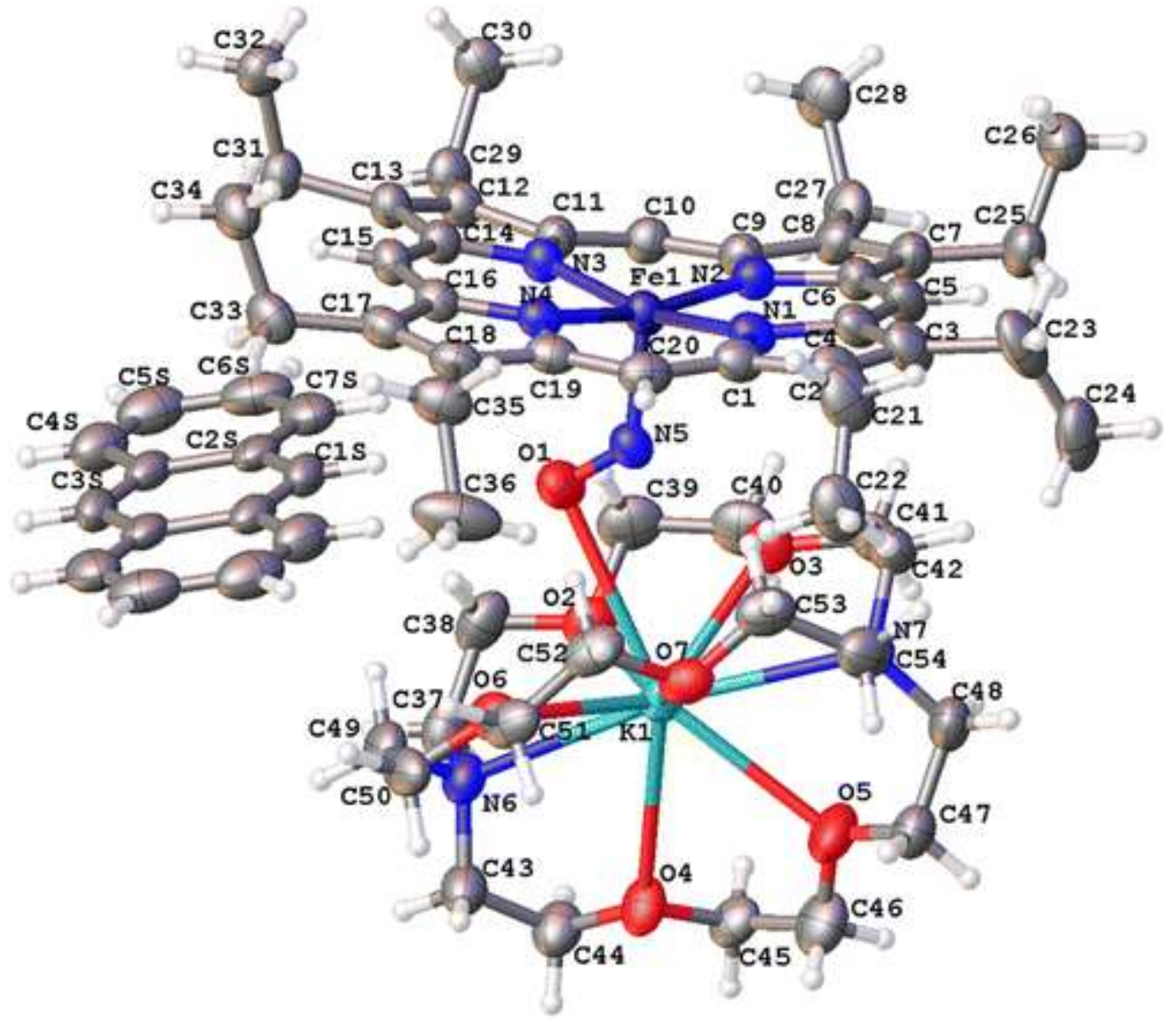

Figure 1. ORTEP diagram for one of the $[\mathrm{K}(2.2 .2)][\mathrm{Fe}(\mathrm{OEP})(\mathrm{NO})]$ units in the asymmetric unit. Ellipsoids are depicted at $50 \%$ probability.

Table 1. Crystal Data and Structure Refinement Details for [K(2.2.2)cryptand][Fe(OEP)(NO)] 0.5(anthracene)

$\begin{array}{ll}\text { empirical formula } & \mathrm{C}_{61} \mathrm{H}_{85} \mathrm{FeKN}_{7} \mathrm{O}_{7} \\ \text { formula wt } & 1123.31 \\ \text { temp/K } & 100.00(10) \\ \text { cryst syst } & \text { triclinic } \\ \text { space group } & P 1 \\ a, \AA & 14.7775(2) \\ b, \AA & 19.6688(3) \\ c, \AA & 21.2458(3) \\ \text { a, deg } & 83.4024(14) \\ \beta, \text { deg } & 88.8922(12)\end{array}$

Inorganic Chemistry, Vol 55, No. 5 (2016): pg. 2070-2075. DOI. This article is ( American Chemical Society and permission has been granted for this version to appear in e-Publications@Marquette. American Chemical Society does not grant permission for this article to be further copied/distributed or hosted elsewhere without the express permission from American Chemical Society. 
NOT THE PUBLISHED VERSION; this is the author's final, peer-reviewed manuscript. The published version may be accessed by following the link in the citation at the bottom of the page.

$\begin{array}{ll}Y, \text { deg } & 73.4501(14) \\ V, \AA^{3} & 5879.61(16) \\ Z & 4 \\ \rho_{\text {calcd, } \mathrm{g} / \mathrm{cm}^{3}} & 1.269 \\ \mu, \mathrm{mm}^{-1} & 3.148 \\ F(000) & 2404.0 \\ \text { cryst size, } \mathrm{mm}^{3} & 0.633 \times 0.139 \times 0.113 \\ \text { radiation } & \mathrm{Cu} \mathrm{Ka}(\lambda=1.54184) \\ 2 \theta \text { range for data collection, deg } & 5.94-148.4 \\ \text { index ranges } & -18 \leq h \leq 18,-23 \leq k \leq 24,-26 \leq I \leq 26 \\ \text { no. of rflns collected } & 111300 \\ \text { no. of indep rflns } & 23568\left(R_{\text {int }}=0.0502, R_{\sigma}=0.0373\right) \\ \text { no. of data/restraints/params } & 23568 / 45 / 1392 \\ \text { goodness of fit on } F^{2} & 1.021 \\ \text { final } R \text { indexes }(I \geq 2 \sigma(I)) & \mathrm{R} 1=0.0625, \mathrm{wR} 2=0.1502 \\ \text { final } R \text { indexes (all data) } & \mathrm{R} 1=0.0797, \mathrm{wR} 2=0.1610 \\ \text { largest diff peak/hole, e } \AA^{-3} & 1.12 /-0.63\end{array}$

Table 2. Selected Crystallographic Determined Parameters and Nitrosyl Infrared Energies for Related Metalloporphyrin Nitrosyl Complexes

\begin{tabular}{|c|c|c|c|c|c|c|c|c|}
\hline complex & & $\mathrm{M}-\mathrm{N}_{\mathrm{NO}}, \boldsymbol{\AA}$ & $\mathbf{N}-\mathbf{O}, \AA$ & $\underset{\left.N_{p}\right)_{a v}, \AA}{(M-}$ & $\begin{array}{c}\text { M-N-O, } \\
\text { deg }\end{array}$ & $\mathrm{V}_{\mathrm{NO}}, \mathrm{cm}^{-1}$ & $\begin{array}{c}E^{\circ}, \mathrm{V} \\
\text { VS } \\
\text { SCE }\end{array}$ & ref \\
\hline $\mathrm{Fe}(\mathrm{OEP})(\mathrm{NO})$ & SC & $1.7307(7)$ & $1.168(1)$ & $2.009(12)$ & $142.74(8)$ & 1673 & $\overline{1.10}$ & 8,16 \\
\hline \multirow[t]{5}{*}[\mathrm{Fe}(\mathrm{OEP})(\mathrm{NO})]{$^{-}$} & SC & $\begin{array}{l}1.812(3) \\
1.816(3)\end{array}$ & $\begin{array}{l}1.187(3) \\
1.203(3)\end{array}$ & $\begin{array}{l}1.993(16) \\
1.993(16)\end{array}$ & $\begin{array}{l}127.2(2) \\
126.8(2)\end{array}$ & $1445(1428)^{a}$ & & $\begin{array}{l}13 \\
\text { this } \\
\text { work }\end{array}$ \\
\hline & $\mathrm{DFT} / \mathrm{m} 06$ & 1.786 & 1.190 & 2.002 & 122 & 1530 & & $\begin{array}{l}\text { this } \\
\text { work }\end{array}$ \\
\hline & $\mathrm{DFT} / \mathrm{m06L}$ & 1.787 & 1.197 & 2.008 & 123 & 1503 & & $\begin{array}{l}\text { this } \\
\text { work }\end{array}$ \\
\hline & DFT/bp86 & 1.783 & 1.207 & 2.012 & 125 & 1527 & & $\begin{array}{l}\text { this } \\
\text { work }\end{array}$ \\
\hline & DFT/mpwrwn & 1.809 & 1.213 & 2.041 & 125 & 1480 & & $\begin{array}{l}\text { this } \\
\text { work }\end{array}$ \\
\hline $\mathrm{Fe}\left(\mathrm{TFPPBr}_{8}\right)(\mathrm{NO})$ & SC & $1.741(5)$ & $1.131(6)$ & $1.988(12)$ & $148.5(4)$ & 1718 & $\overline{0} .16$ & 20,21 \\
\hline$\left[\mathrm{Fe}\left(\mathrm{TFPPBr}_{8}\right)(\mathrm{NO})\right]^{-}$ & SC & $1.814(4)$ & $1.194(5)$ & $1.972(11)$ & $122.4(3)$ & 1540 & & 21 \\
\hline \multirow[t]{2}{*}[\mathrm{Fe}(\text{porphine})(\mathrm{NO})]{$^{-}$} & DFT & 1.798 & 1.211 & & 123 & 1530 & & 20 \\
\hline & DFT & 1.786 & 1.206 & 2.011 & 125 & 1533 & & 14 \\
\hline \multirow[t]{2}{*}{$\mathrm{Co}(\mathrm{OEP})(\mathrm{NO})$} & $\mathrm{SC}$ & $1.8444(9)$ & $1.164(1)$ & $1.984(8)$ & $123.4(2)$ & 1677 & $\overline{1.15^{\mathrm{b}}}$ & 29,30 \\
\hline & SC & $1.844(2)$ & $1.152(3)$ & $1.985(9)$ & $123.39(5)$ & 1675 & & 31 \\
\hline
\end{tabular}

As was observed for $\left[\mathrm{Fe}\left(\mathrm{TFPPBr}_{8}\right)(\mathrm{NO})\right]^{-}(3),{ }^{21}$ the $\mathrm{Fe}-\mathrm{N}-\mathrm{O}$ bond angle decreased significantly when the nitrosyl complex was reduced.

Inorganic Chemistry, Vol 55, No. 5 (2016): pg. 2070-2075. DOI. This article is ( American Chemical Society and permission has been granted for this version to appear in e-Publications@Marquette. American Chemical Society does not grant permission for this article to be further copied/distributed or hosted elsewhere without the express permission from American Chemical Society. 
For 2, the bond angle (average) decreased from 144 to $127^{\circ}$, a decrease of $17^{\circ}(\mathrm{Fe}-\mathrm{N}-\mathrm{O}$ angles for each anion $126.8(2)$ and $\left.127.2(2)^{\circ}\right)$. This compares to a slightly smaller bond angle of $122.4^{\circ}$ for 3. The $\mathrm{Fe}-\mathrm{N}-\mathrm{O}$ bond angle of $\mathbf{3}$ and the $\mathrm{Co}-\mathrm{N}-\mathrm{O}$ bond angle of $\mathrm{Co}(\mathrm{OEP})(\mathrm{NO})$ were similar $\left(3,122.4^{\circ} ; \mathrm{Co}(\mathrm{OEP})(\mathrm{NO}), 122.7\right.$ and $\left.123.4^{\circ}\right)$; all three structures had bond angles smaller than the angle in $[\mathrm{Fe}(\mathrm{OEP})(\mathrm{NO})]^{-}$. The $\mathrm{Fe}-\mathrm{N}-\mathrm{O}$ angle was consistent with the formation of a $\{\mathrm{FeNO}\}^{8}$ structure. Upon reduction, the tilt angle for $\mathrm{Fe}-\mathrm{N}$ decreased from $6^{\circ}$ to $8^{\circ}$ in $\mathbf{1}$ and to $2^{\circ}$ in $\mathbf{2}$. The $\mathrm{N}-\mathrm{O}$ bond length (average) in $\mathbf{2}$ was $1.195 \AA$, which was essentially the same as the bond length in $\mathbf{3}$ (1.194 $\AA$ ).

The distances between the potassium ion and the nearest atom of the axial ligand are within the range observed for other metalloporphyrins. For example, comparing salts with a $\mathrm{K}(2.2 .2)$ cation, a shorter $\mathrm{K}-\mathrm{N}$ distance of $2.957 \AA$ was observed for $\mathrm{K}^{+}(2.2 .2)\left[\mathrm{Fe}(\mathrm{TPP})(\mathrm{CN})_{2}\right]^{2-}{ }^{33}$ while a longer $\mathrm{K}-\mathrm{O}$ distance was seen in $\left[\mathrm{Co}^{\mathrm{III}}(\mathrm{TPP})(\mathrm{NCO})_{2}\right]^{-}(3.407 \AA) \cdot{ }^{34}$ The interaction of the cation with the $\mathrm{Fe}(\mathrm{P})(\mathrm{NO})^{-}$anion is significantly different in our work as compared to that of $\mathrm{Hu}$ and $\mathrm{Li}^{21}$ In $\mathrm{Hu}$ and Li's work, the $\mathrm{N}-\mathrm{O}$ moiety was directed away from the cation, $\left[\mathrm{Co}(\mathrm{Cp})_{2}\right]^{+}$, which showed no specific interaction with the anion. In our work, the distances were relatively short (around $3.2 \AA$ ) between $\mathrm{K} 1$ and 01 , similar to the potassium cryptand salt of $\left[\mathrm{Fe}^{\mathrm{II}}(\mathrm{TPP})(\mathrm{CN})_{2}\right]^{-}$, where there was a similar interaction between the $\mathrm{K}(2.2 .2)$ ion and the $\mathrm{N}$ atom of the cyanide ligands. This is consistent with a contact ion pair, on the basis of the work of Davlieva et al. ${ }^{35}$

The average $\mathrm{Fe}-\mathrm{N}_{\mathrm{p}}$ bond distance decreased upon reduction from $2.009 \AA$ ( $2.004 \AA$ for structure $B)$ to $1.993 \AA(0.016 / 0.011 \AA)$, where $N_{p}$ is the average distance between the iron atom and the four pyrrole nitrogens of OEP. This decrease was similar to that observed for $\left[\mathrm{Fe}\left(\mathrm{TFPPBr}_{8}\right)(\mathrm{NO})\right]^{-}$, where the average distance decreased from 1.988 to $1.972 \AA(0.016 \AA)$. For $\mathrm{Fe}(\mathrm{OEP})(\mathrm{NO})$, the displacements of $\mathrm{Fe}$ from the 24-atom porphyrin ring ${ }^{16}$ were 0.29 and $0.27 \AA$ for the two structures, while the Fe displacement for $[\mathrm{Fe}(\mathrm{OEP})(\mathrm{NO})]^{-}$was found to be $0.28 \AA$. This contrasts with $\mathrm{Fe}\left(\mathrm{TFPPBr}_{8}\right)(\mathrm{NO})$, where the $\mathrm{Fe}$ displacement decreased from 0.36 to $0.19 \AA$ upon reduction. 
A small degree of ruffling was observed for the starting complex, $\mathrm{Fe}(\mathrm{OEP})(\mathrm{NO})$. The average deviation from the 24-atom plane was found to be 0.031 and $0.044 \AA$ for the two structures that have been characterized. ${ }^{16}$ Upon reduction, there was a significant increase in the nonplanarity of the porphyrin ring. This can be visually seen by the green structure in Figure 2. The average deviation of each atom in 2 from the 24-atom plane was $0.12 \AA, 2-3$ times larger than in $\mathrm{Fe}(\mathrm{OEP})(\mathrm{NO})$ (see Figure $2 \mathrm{~B}$ for the individual displacements of $[\mathrm{Fe}(\mathrm{OEP})(\mathrm{NO})]^{-}$; there were no significant differences between the two anions in the unit cell). A comparison of $\mathrm{Fe}(\mathrm{OEP})(\mathrm{NO})$ (structure A) with $\mathbf{2}$ is shown in Figure 2, where $\mathbf{2}$ is the green structure and $\mathbf{1}$ is the pink structure. As can be seen, the nitroxyl is more saddled than the starting nitrosyl. The ruffling and saddling in $\mathbf{3}$ was significantly larger than in $\mathbf{2}(0.49 \AA$ versus $0.12 \AA)$, but the starting complex for $\mathbf{3}$ was already significantly saddled $(0.51 \AA) .{ }^{21}$ Therefore, it would be difficult to detect and interpret changes that occurred upon the formation of 3 .

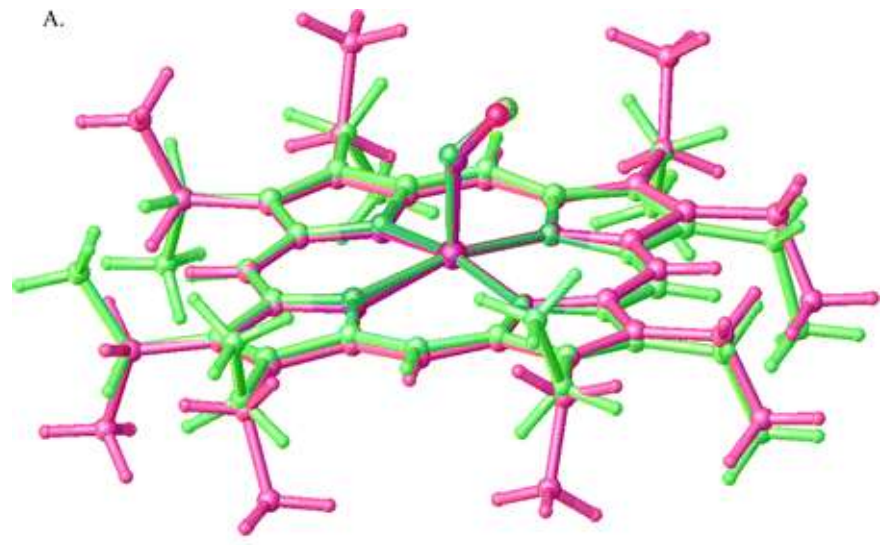

B.

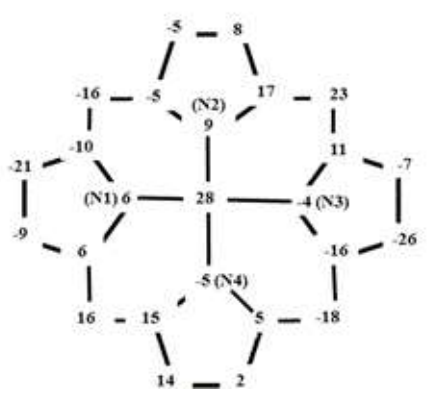

Figure 2. (A) Comparison of $[\mathrm{Fe}(\mathrm{OEP})(\mathrm{NO})]^{-}$(green) with $\mathrm{Fe}(\mathrm{OEP})(\mathrm{NO})^{16}$ (structure $A$ in the reference, pink). Hydrogens have been omitted for clarity. (B) Porphyrin core diagram that indicates the out-of-plane displacements of the atoms from the 24-atom porphyrin plane of $[\mathrm{Fe}(\mathrm{OEP})(\mathrm{NO})]^{-}$(first structure in unit cell, $\left.\mathrm{F} 1-\mathrm{C} 54\right)$. Displacements are given in units of $0.01 \AA$. Positive displacements are toward the nitroxyl group. Nitrogen atoms are labeled for orienting the ion. The nitroxyl is between N3 and N4. 
For comparison, DFT was used to calculate the structure and infrared spectrum of $[\mathrm{Fe}(\mathrm{OEP})(\mathrm{NO})]^{-}$, using the $\mathrm{m06}, \mathrm{m06}$, mpwrwn, and bp86 functionals. The results are shown in Table 2 . The infrared spectra of $[\mathrm{Fe}(\mathrm{OEP})(\mathrm{NO})]^{-}$(natural abundance) and $\left[\mathrm{Fe}(\mathrm{OEP})\left({ }^{15} \mathrm{NO}\right)\right]^{-}$ are shown in Figure 3. The $\mathrm{v}_{\mathrm{NO}}$ values observed for the solid nitroxyl complexes are consistent with those previously reported by spectroelectrochemistry. ${ }^{13}$ For many parameters, there was good agreement between the calculated and experimental values. The two distances for the length of the $\mathrm{N}-\mathrm{O}$ bond in the two anions within the asymmetric unit were within the range predicted by the DFT calculations (DFT, 1.190 and $1.213 \AA$; experimental, 1.187 and 1.203 $\AA)$. The Fe-NO distances by DFT were shorter than the experimental value, while the experimental Fe-N-O angle $\left(127^{\circ}\right)$ was only slightly larger than the DFT values $\left(122-125^{\circ}\right)$. On the one hand, the $\mathrm{Fe}-\mathrm{N}_{\mathrm{p}}$ value was shorter $(1.993 \AA)$ than the predicted values $(2.002-2.012$ $\AA)$. On the other hand, the presence of two short and two long Fe-N bond distances was observed in both the experimental and DFT structures, in common with the $\mathrm{Fe}(\mathrm{OEP})(\mathrm{NO})$ starting complex. The DFT calculations all predicted shorter $\mathrm{Fe}-\mathrm{N}_{\mathrm{NO}}$ distances $(1.783-1.787$ $\AA)$ than were observed in the crystal structure (1.812 $\AA)$. This indicates a weaker $\mathrm{Fe}-\mathrm{N}_{\mathrm{NO}}$ bond than was predicted by the calculations. The lengthening of the $\mathrm{N}-\mathrm{O}$ bond was consistent with the occupation of the $\Pi^{*}$ orbital in $\mathrm{N}-\mathrm{O}$. This can be seen in the HOMO of $[\mathrm{Fe}(\mathrm{OEP})(\mathrm{NO})]^{-}$(Figure $4 \mathrm{~A}$ ), which was obtained from the m06/DFT calculations. NBO calculations of $\mathbf{1}$ and $\mathbf{2}$ show no significant change in the $d$ orbital occupation of the iron atom, indicating little to no reduction of the iron itself. While there was considerable consistency in the DFT calculated structures between the functionals, there were differences in the electron distribution. The best correlation between the $d$ orbital occupation and the IR frequency was for the sum of the $\mathrm{d}_{x}{ }^{2}-y^{2} / \mathrm{d}_{z}{ }^{2}$ orbitals. The sum was smallest for $\mathrm{m06}\left(2.010, \mathrm{v}_{\mathrm{NO}} 1530 \mathrm{~cm}^{-}\right.$ $\left.{ }^{1}\right)$. As the sum of the $d_{x}{ }^{2}-y^{2} / d_{z}{ }^{2}$ orbitals increased, the calculated $\mathrm{V}_{\mathrm{NO}}$ frequency decreased (bp86, 2.090, $\mathrm{V}_{\mathrm{NO}} 1527 \mathrm{~cm}^{-1} ; \mathrm{m06L}, 2.195, \mathrm{v}_{\mathrm{NO}}$ $1503 \mathrm{~cm}^{-1}$; mpwvwn, 2.293, $\mathrm{v}_{\mathrm{NO}} 1480 \mathrm{~cm}^{-1}$ ) 


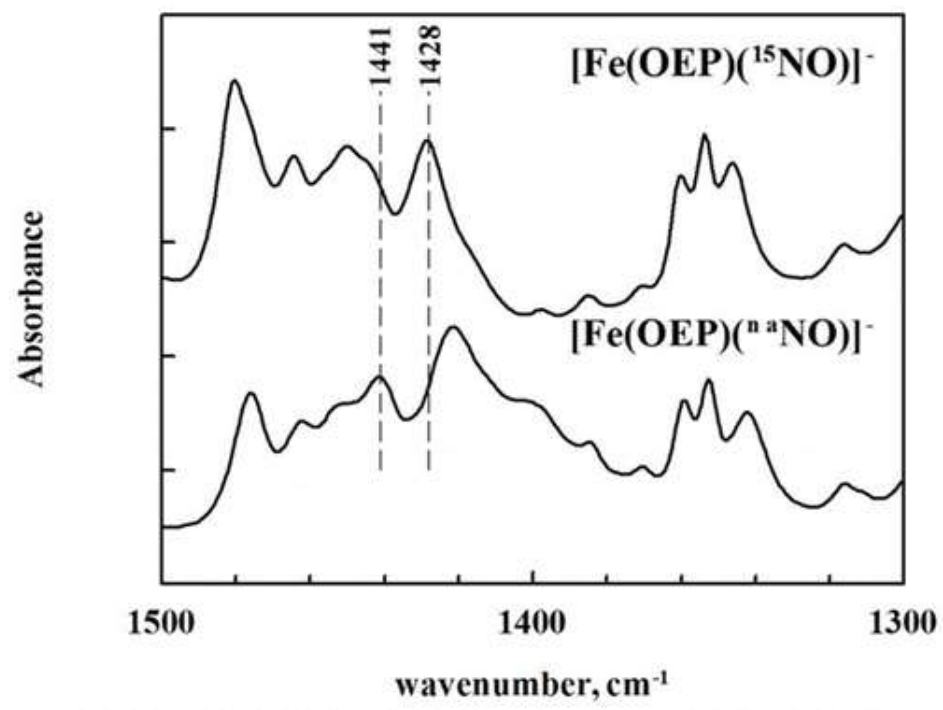

Figure 3. FTIR spectra of $[K(2.2 .2)]\left[\mathrm{Fe}(\mathrm{OEP})\left({ }^{\text {na } N O}\right)\right]$ and $[\mathrm{K}(2.2 .2)]\left[\mathrm{Fe}(\mathrm{OEP})\left({ }^{15} \mathrm{NO}\right)\right]$ in $\mathrm{KBr}$ pellets, where na = natural abundance. Frequencies shown are for $\mathrm{v}_{\mathrm{NO}}$ (1441 $\mathrm{cm}^{-1}$ for natural abundance, $1428 \mathrm{~cm}^{-1}$ for ${ }^{15} \mathrm{~N}$ isotopomer).
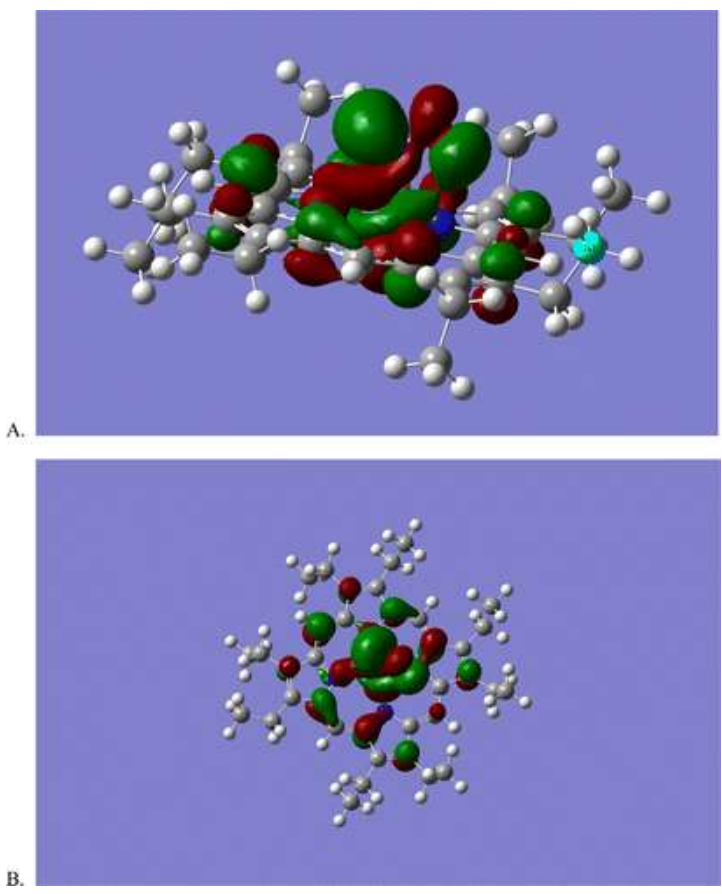

Figure 4. Two views of the HOMO orbital for $[\mathrm{Fe}(\mathrm{OEP})(\mathrm{NO})]^{-}$as calculated using DFT and the m06L functional: (A) side view; (B) top view.

Within the porphyrin ring, the $\mathrm{C}_{\beta}-\mathrm{C}_{\beta}$ bonds shortened slightly from $1.365 / 1.360 \AA$ in the two $\mathrm{Fe}(\mathrm{OEP})(\mathrm{NO})$ structures to $1.357 \AA$ in 2. Given the differences in the two structures of $\mathbf{1}$, this decrease is probably not significant and is consistent with little to no electron

Inorganic Chemistry, Vol 55, No. 5 (2016): pg. 2070-2075. DOI. This article is C American Chemical Society and permission has been granted for this version to appear in e-Publications@Marquette. American Chemical Society does not grant permission for this article to be further copied/distributed or hosted elsewhere without the express permission from American Chemical Society. 
density at these positions in the HOMO (Figure 4B). The average $\mathrm{C}_{\text {meso }}$ bonds were essentially unchanged upon reduction $(1.383 / 1.379 \AA$ in $\mathbf{1}$ to $1.381 \AA$ in $\mathbf{2}$ ). On the other hand, while the distances from the $C_{\text {meso }}$ to the two adjacent $C_{a}$ atoms differed little in $\mathbf{1}$ (maximum difference $0.005 \AA$ ), there was significantly more asymmetry in $\mathbf{2}$. While one set of bonds was reasonably symmetrical (1.381/1.379 $\AA$ ), the other three were much more asymmetrical, going from $1.389 / 1.378 \AA$ to $1.392 / 1.374 \AA$. While this asymmetry was not observed in the DFT calculations, the HOMO orbital in Figure 4B shows bonding interactions between some of the $\mathrm{C}_{\text {meso }}$ atoms and $\mathrm{C}_{a}$ of one pyrrole, but no electron density between the same $C_{\text {meso }}$ and the other pyrrole $C_{a}$. Therefore, the bonding interaction, leading to the asymmetry, is predicted by DFT but is experimentally stronger than that predicted. Therefore, as was seen with the $\mathrm{C}_{\text {meso }}-\mathrm{C}_{a}$ distances, the changes predicted by DFT are in the right direction but are underestimated. Additionally, DFT calculations predicted no significant changes in the planarity of the porphyrin ring upon reduction (DFT: average deviation of $0.036 \AA$ in $\mathbf{1}$ versus $0.038 \AA$ in $\mathbf{2}$ ).

In calculating the infrared spectra by DFT, it was found from previous studies on related complexes ${ }^{25}$ that a scale factor of 0.94 was appropriate for the m06 functional and 1.0 for the bp86 and mpwvwn functionals, though the bp86 functional tended to underestimate the vibrational energies. The results are shown in Table 2. All of the DFT calculations predict a large decrease in the $\mathrm{v}_{\mathrm{N}}$ band upon reduction (1480-1530 $\mathrm{cm}^{-1}$ ), though none of them predicted correctly the measured wavenumber $\left(1441 \mathrm{~cm}^{-1}\right)$. The mpwvwn functional gave the best agreement $\left(1480 \mathrm{~cm}^{-1}\right)$, which is consistent with the work of Ling et al. ${ }^{36}$ who had previously reported excellent agreement with this functional and the experimental values for nitrosyl complexes.

While $[\mathrm{Fe}(\mathrm{OEP})(\mathrm{NO})]^{-}$is a $S=0$ complex, the NMR spectrum was significantly different from those of other $S=0$ metalloporphyrin complexes. Typical values of chemical shifts for such porphyrins, e.g., $\mathrm{Mg}^{\mathrm{II}}(\mathrm{OEP})$ and $\mathrm{Fe}^{\mathrm{II}}(\mathrm{OEP})$ (pyridine)2, are $10.0 \mathrm{ppm}$ for the mesoprotons and 4.0 and 1.9 ppm for the methylene and methyl protons, respectively. ${ }^{37,38}$ The proton NMR spectrum for $\mathbf{2}$ showed no resonances around $10 \mathrm{ppm}$, in contrast to what has been seen for typical of $S=0$ metalloporphyrins. Resonances for anthracene were 
observed at 7.4, 7.95, and 8.4 ppm (indicated by asterisks in Figure 5). Additional resonances were observed at 7.50, 7.57, and 7.77 ppm, which are attributed to $[\mathrm{Fe}(\mathrm{OEP})(\mathrm{NO})]^{-}$. In order to confirm this, the NMR chemical shifts were calculated using Gaussian 09. Resonances for the meso proton resonances were predicted at 7.0 and $7.7 \mathrm{ppm}$. For comparison, the NMR spectrum of $\mathrm{Zn}(\mathrm{OEP})(S=0)$ was calculated using Gaussian, and the calculated chemical shift was found to be 10.7 ppm (experimental: $10.1 \mathrm{ppm}^{39}$ ). The average calculated resonances by Gaussian for the methylene and methyl protons in $\mathrm{Fe}(\mathrm{OEP})(\mathrm{NO})^{-}$ were 3.1 and $1.4 \mathrm{ppm}$. This compares to the experimental values of 4.1 and $1.9 \mathrm{ppm}$ for the methylene and methyl protons of $\mathrm{Mg}(\mathrm{OEP})$ and the calculated values for $\mathrm{Zn}(\mathrm{OEP})$ of 4.4 and $2.0 \mathrm{ppm}$. Resonances were observed for $[\mathrm{Fe}(\mathrm{OEP})(\mathrm{NO})]^{-}$at $0.9 / 1.3 \mathrm{ppm}$ (methyl) and 3.3/3.9 ppm (methylene), both upshifted from the $S=0$ values, as predicted by DFT. Further confirmation was obtained by the synthesis of $\left[\mathrm{Fe}\left(\mathrm{OEP}-d_{4}\right) \mathrm{NO}^{-}\right.$, where the meso protons were replaced by deuterium atoms. Figure 5 shows a comparison between the naturalabundance and $d_{4}$ forms of $[\mathrm{Fe}(\mathrm{OEP})(\mathrm{NO})]^{-}$. In the $d_{4}$ complex, the resonances attributed to the meso protons were missing or highly attenuated. This spectrum is unusual in comparison to those for other $S=0$ complexes. To test whether the chemical shift and splitting for the meso protons were due to the displacement of the iron atom, the DFT calculations for $[\mathrm{Fe}(\mathrm{OEP})(\mathrm{NO})]^{-}$, where the Fe atom was moved into the plane defined by the four pyrrole nitrogens (while maintaining the $\mathrm{Fe}-\mathrm{N}-\mathrm{O}$ bond lengths and angle), were performed. This calculation showed that the average $\delta$ value decreased from 7.6 to 9.2 , closer to the experimental value for $S=0$ metalloporphyrins, but the splitting of the meso protons was more pronounced. Both DFT calculations (Fe out of plane and in plane) showed that the meso protons that were displaced toward the NO group had $\delta$ values lower than those displaced away from the NO group. Attempts to mimic this with a fivecoordinate $S=0$ complex (zinc octaethylporphyrin) in the presence of an excess of 1 -methylimidazole- $d_{3}$ were inconclusive. The complex did show a small decrease in the chemical shift of the meso resonances (10.18 to 9.99) but no splitting of the meso protons. This shift may have been attenuated because of the facile exchange of the imidazole ligand and the fact that the complex was weak. The most likely source of the splitting of the meso protons may be due to slow rotation of the $\mathrm{NO}^{-}$ligand around the iron. Slow rotation of the $\mathrm{NO}^{-}$moiety would

Inorganic Chemistry, Vol 55, No. 5 (2016): pg. 2070-2075. DOI. This article is ( American Chemical Society and permission has been granted for this version to appear in e-Publications@Marquette. American Chemical Society does not grant permission for this article to be further copied/distributed or hosted elsewhere without the express permission from American Chemical Society. 
more closely mimic the DFT calculations. Further studies are in progress on this issue.

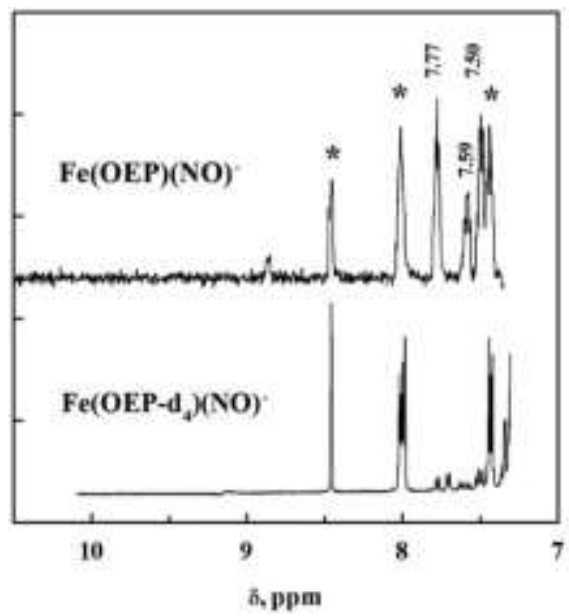

Figure 5. ${ }^{1} \mathrm{H}$ NMR spectra for $[\mathrm{Fe}(\mathrm{OEP})(\mathrm{NO})]^{-}$(natural abundance and $d_{4}$ isotopomer). Peaks with asterisks indicate resonances for anthracene. Chemical shifts $(\delta)$ for resonances of meso protons are shown.

\section{Conclusions}

The changes in the planarity from $\mathbf{1}$ to $\mathbf{2}$ were an unexpected result of the reduction. DFT calculations had predicted minor changes. The most significant changes in bond distances were the $C_{\text {meso }}$ to $C_{a}$ distances, where the differences in the two $\mathrm{C}_{\text {meso }}-\mathrm{C}_{a}$ distances are probably the sources of the saddling of the complex. While such asymmetry was not predicted by the DFT calculations, the presence of bonding interactions in the HOMO between the $\mathrm{C}_{\text {meso }}$ and one of the $\mathrm{C}_{a}$ atoms is probably the source of this difference. This saddling is not necessarily a consequence of low-valent iron porphyrins, as $\mathrm{Fe}(\mathrm{TPP})^{-}$ has an average deviation of less than $\pm 0.05 \AA .{ }^{40}$ The metal- $\mathrm{N}-\mathrm{O}$ angle in the complex was quite similar to those of other $\{\mathrm{M}-\mathrm{N}-\mathrm{O}\}^{8}$ complexes such as 3 and $\mathrm{Co}(\mathrm{OEP})(\mathrm{NO}) .{ }^{28}$ Little change was observed in the displacement of the iron atom from the plane in the formation of $\mathbf{2}$, unlike the changes observed in the formation of $3 .^{21}$ In both $\mathbf{2}$ and $\mathbf{3}$, the average $\mathrm{Fe}-\mathrm{N}_{\mathrm{p}}$ bond distances decreased by a similar amount. The decrease in the $\mathrm{v}_{\mathrm{NO}}$ band upon reduction was consistent with the increase in the $\mathrm{N}-\mathrm{O}$ bond length, but the DFT calculations consistently underestimated the wavenumber decrease. Finally, the iron porphyrin nitroxyl showed a unique ${ }^{1} \mathrm{H}$ NMR spectrum for $\mathbf{2}$, but the spectrum was consistent with DFT calculations. Overall, the results of this work confirm that the primary site of the reduction of low-spin heme $\{\mathrm{Fe}-$ 
$\mathrm{NO}\}^{7}$ complexes is on the nitrosyl moiety, as has been observed elsewhere. ${ }^{14}$ This result is in strong contrast to the non-heme $\left\{\mathrm{FeNO}^{7}{ }^{7}\right.$, where the reduction is centered on the iron in forming the $\{\text { FeNO }\}^{8}$ complex. ${ }^{41}$ This difference is also reflected in the redox potentials, which is much more negative for the heme $\{\mathrm{Fe}-\mathrm{NO}\}^{7}$ complexes.

The authors declare no competing financial interest.

\section{References}

1 Fukuto, J. M.; Dutton, A. S.; Houk, K. N. ChemBioChem 2005, 6, 612- 619, DOI: $10.1002 /$ cbic. 200400271

2 Paolocci, N.; Katori, T.; Champion, H. C.; St. John, M. E.; Miranda, K. M.; Fukuto, J. M.; Wink, D. A.; Kass, D. A. Proc. Natl. Acad. Sci. U. S. A. 2003, 100, 5537- 5542, DOI: 10.1073/pnas.0937302100

3 Irvine, J. C.; Ritchie, R. H.; Favaloro, J. L.; Andrews, K. L.; Widdop, R. E.; Kemp-Harper, B. K. Trends Pharmacol. Sci. 2008, 29, 601-608, DOI: 10.1016/j.tips.2008.08.005

4 Hino, T.; Matsumoto, Y.; Nagano, S.; Sugimoto, H.; Fukumori, Y.; Murata, T.; Iwata, S.; Shiro, Y. Science 2010, 330, 1666- 1670, DOI: 10.1126/science. 1195591

5 Nakahara, K.; Tanimoto, T.; Hatano, K.; Usuda, K.; Shoun, H. J. Biol. Chem. 1993, 268, 8350- 8355

6 Daiber, A.; Shoun, H.; Ullrich, V. J. Inorg. Biochem. 2005, 99, 185- 193, DOI: $10.1016 /$ j.jinorgbio.2004.09.018

7 Speelman, A. L.; Lehnert, N. Acc. Chem. Res. 2014, 47, 1106-1116, DOI: 10.1021/ar400256u

8 Olson, L. W.; Schaeper, D.; Lançon, D.; Kadish, K. M. J. Am. Chem. Soc. 1982, 104, 2042- 2044, DOI: 10.1021/ja00371a051

9 Lançon, D.; Kadish, K. M. J. Am. Chem. Soc. 1983, 105, 5610- 5617, DOI: 10.1021/ja00355a014

10 Choi, I.-K.; Ryan, M. D. Inorg. Chim. Acta 1988, 153, 25- 30, DOI: 10.1016/S0020-1693(00)83352-6

$11 \mathrm{Mu}$, X. H.; Kadish, K. M. Inorg. Chem. 1988, 27, 4720- 4725, DOI: 10.1021/ic00299a009

12 Choi, I.-K.; Liu, Y.; Feng, D.; Paeng, K. J.; Ryan, M. D. Inorg. Chem. 1991, 30, 1832-1839, DOI: 10.1021/ic00008a028

13 Wei, Z.; Ryan, M. D. Inorg. Chem. 2010, 49, 6948-6954, DOI: 10.1021/ic100614h

14 Goodrich, L. E.; Roy, S.; Alp, E. E.; Zhao, J.; Hu, M. Y.; Lehnert, N. Inorg. Chem. 2013, 52, 7766- 7780, DOI: 10.1021/ic400977h

Inorganic Chemistry, Vol 55, No. 5 (2016): pg. 2070-2075. DOI. This article is ( American Chemical Society and permission has been granted for this version to appear in e-Publications@Marquette. American Chemical Society does not grant permission for this article to be further copied/distributed or hosted elsewhere without the express permission from American Chemical Society. 
NOT THE PUBLISHED VERSION; this is the author's final, peer-reviewed manuscript. The published version may be

accessed by following the link in the citation at the bottom of the page.

15 Scheidt, W. R.; Frisse, M. E. J. Am. Chem. Soc. 1975, 97, 17- 21, DOI: 10.1021/ja00834a005

16 Scheidt, W. R.; Duval, H. F.; Neal, T. J.; Ellison, M. K. J. Am. Chem. Soc. 2000, 122, 4651-4659, DOI: 10.1021/ja993995y

17 Bohle, D. S.; Hung, C. H. J. Am. Chem. Soc. 1995, 117, 9584- 9585, DOI: 10.1021/ja00142a035

18 Nasri, H.; Haller, K. J.; Wang, Y.; Huynh, B. H.; Scheidt, W. R. Inorg. Chem. 1992, 31, 3459- 3467, DOI: 10.1021/ic00042a023

19 Scheidt, W. R.; Lee, Y. J.; Hatano, K. J. Am. Chem. Soc. 1984, 106, 31913198, DOI: $10.1021 / \mathrm{ja00323a022}$

20 Pellegrino, J.; Bari, S. E.; Bikiel, D. E.; Doctorovich, F. J. Am. Chem. Soc. 2010, 132, 989- 995, DOI: 10.1021/ja905062w

$21 \mathrm{Hu}, \mathrm{B} . ;$ Li, J. Angew. Chem., Int. Ed. 2015, 54, 10579- 10582, DOI: 10.1002/anie.201505166

22 Liu, Y. M.; DeSilva, C.; Ryan, M. D. Inorg. Chim. Acta 1997, 258, 247255, DOI: $10.1016 /$ S0020-1693(96)05547-8

23 Bonnett, R.; Gale, I. A. D.; Stephenson, G. F. J. Chem. Soc. C 1967, 11681172, DOI: $10.1039 / \mathrm{j} 39670001168$

${ }^{24}$ Frisch, M. J.; Trucks, G. W.; Schlegel, H. B.; Scuseria, G. E.; Robb, M. A.; Cheeseman, J. R.; Scalmani, G.; Barone, B.; Mennucci, B.; Petersson, G. A.; Natatsuji, H.; Caricota, M.; Li, X.; Hratchian, H. P.; Izmaylov, A. F.; Bloino, J.; Zheng, G.; Sonnenberg, J. L.; Hada, M.; Ehara, M.; Toyota, K.; Fukuda, R.; Hasegawa, J.; Ishida, M.; Nakajima, T.; Honda, Y.; Kitao, O.; Nakai, H.; Vreven, T.; Montgomery, J. A., Jr.; Peralta, J. E.; Ogliaro, F.; Bearpark, M.; Heyd, J. J.; Brothers, E.; Kudin, K. N.; Staroverov, V. N.; Kobayashi, R.; Normand, J.; Raghavachari, K.; Rendell, A.; Burant, J. C.; Iyengar, S. S.; Tomasi, J.; Cossi, M.; Rega, N.; Millam, N. J.; Klene, M.; Knox, J. E.; Cross, J. B.; Bakken, V.; Adamo, C.; Jaramillo, J.; Gomperts, R.; Stratmann, R. E.; Yazyev, O.; Austin, A. J.; Cammi, R.; Pomelli, C.; Ochterski, J. W.; Martin, R. L.; Morokuma, K.; Zakrzewski, V. G.; Voth, G. A.; Salvador, P.; Dannenberg, J. J.; Dapprich, S.; Daniels, A. D.; Ö. Farkas;

Foresman, J. B.; Ortiz, J. V.; Cioslowski, J.; Fox, D. J. Gaussian 09, Revision D.01; Gaussian, Inc., Wallingford, CT, 2009.

25 Tutunea, F.; Atifi, A.; Ryan, M. D. J. Electroanal. Chem. 2015, 744, 17- 24, DOI: $10.1016 / j$ jelechem.2015.02.024

26 Tutunea, F.; Ryan, M. D. J. Electroanal. Chem. 2012, 670, 16- 22, DOI: 10.1016/j.jelechem.2012.01.027

27 Wachters, A. J. H. J. Chem. Phys. 1970, 52, 1033-1036, DOI: 10.1063/1.1673095

28 Fujita, E.; Fajer, J. J. Am. Chem. Soc. 1983, 105, 6743- 6745, DOI: 10.1021/ja00360a049

Inorganic Chemistry, Vol 55, No. 5 (2016): pg. 2070-2075. DOI. This article is ( American Chemical Society and permission has been granted for this version to appear in e-Publications@Marquette. American Chemical Society does not grant permission for this article to be further copied/distributed or hosted elsewhere without the express permission from American Chemical Society. 
29 Ellison, M. K.; Scheidt, W. R. Inorg. Chem. 1998, 37, 382- 383, DOI: 10.1021/ic971109j

30 Kelly, S.; Lançon, D.; Kadish, K. M. Inorg. Chem. 1984, 23, 1451- 1458, DOI: 10.1021 ic00178a030

31 Godbout, N.; Sanders, L. K.; Salzmann, R.; Havlin, R. H.; Wojdelski, M.; Oldfield, E. J. Am. Chem. Soc. 1999, 121, 3829-3844, DOI: $10.1021 /$ ja9832820

32 Busing, W. R.; Levy, H. A. Acta Crystallogr. 1964, 17, 142- 146, DOI: $10.1107 / \mathrm{S} 0365110 \times 64000408$

33 Li, J.; Noll, B. C.; Schulz, C. E.; Scheidt, W. R. Angew. Chem., Int. Ed. 2009, 48, 5010- 5013, DOI: 10.1002/anie.200901434

34 Belhaj Ali, B.; Belkhiria, M. S.; Daran, J. C.; Nasri, H. Acta Crystallogr., Sect. E: Struct. Rep. Online 2012, 68, m1262- m1263, DOI: 10.1107/S1600536812038317

35 Davlieva, M. G.; Lü, J. M.; Lindeman, S. V.; Kochi, J. K. J. Am. Chem. Soc. 2004, 126, 4557- 4565, DOI: 10.1021/ja049856k

36 Yang, L.; Ling, Y.; Zhang, Y. J. Am. Chem. Soc. 2011, 133, 13814- 13817, DOI: $10.1021 / \mathrm{ja} 204072 \mathrm{j}$

37 Dolphin, D.; Sams, J. R.; Tsin, T. B.; Wong, K. L. J. Am. Chem. Soc. 1976, 98, 6970-6975, DOI: 10.1021/ja00438a037

38 Buchler, J. W.; Eikelmann, G.; Puppe, L.; Rohbock, K.; Schneehage, H. H.; Weck, D. Ann. Chem. 1971, 745, 135-151, DOI: 10.1002/jlac. 19717450117

39 Fuhrhop, J. H. Z. Naturforsch., B: J. Chem. Sci. 1970, 25, 255- 265, DOI: 10.1515/znb-1970-0305

40 Mashiko, T.; Reed, C. A.; Haller, K. J.; Scheidt, W. R. Inorg. Chem. 1984, 23, 3192- 3196, DOI: 10.1021/ic00188a032

41 Speelman, A. L.; Lehnert, N. Angew. Chem., Int. Ed. 2013, 52, 1228312287, DOI: $10.1002 /$ anie.201305291 